\title{
Um projeto para o Serviço Social crítico
}

\author{
A critical Social Work prolect
}

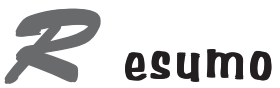

As transformações sociais contemporâneas, operadas pela programática neoliberal sob o comando do capital financeiro, trazem novos desafios ao conjunto de cidadãos e de homens e mulheres que vivem da venda de sua força de trabalho. Os assistentes sociais, individual e coletivamente, não são alheios a esta realidade. A profissão já se caracterizou por enfrentar estes desafios, questionando e problematizando seu papel na sociedade, tentando assumir perfis mais críticos e comprometidos com os interesses dos trabalhadores e dos setores subalternos. Exemplo disso são o "Movimento de Reconceptualização" e a posterior tentativa de definir um "Serviço Social Alternativo" preocupado com o sentido de sua prática, com o processo de conhecimento crítico, com a crítica ao capitalismo e às situações de injustiça social. Os desafios atuais levam a, superando anteriores debilidades, construir coletivamente um projeto éticopolítico profissional que possa enfrentar com competência e compromisso, no interior das forças sociais progressistas, as condições nas quais vivem os trabalhadores (com e sem emprego) e os demais setores subalternos.

Palavras-chave: Serviço Social crítico, projeto ético-político, Serviço Social e neoliberalismo.

\section{Tostract}

Contemporary social transformations, operated by the neoliberal program under the command of financial capital, bring new challenges to the group of citizens and men and women who live by the sale of their labor power. Social workers, individually and collectively, are not separate from this reality. The profession was characterized by its confrontation with these challenges and its questioning and analysis of its role in society, in its attempt to assume more critical profiles and commitments to the interests of workers and the subaltern sectors. An example of this is the "Reconceptualization Movement" and the later attempt to define an "Alternative Social Service" concerned with the meaning of its practice, with the process of critical knowledge, with a criticism of capitalism and its situations of social injustice. The current challenges include overcoming earlier weaknesses, collectively constructing an ethicalpolitical professional project that can competently and committedly confront, at the heart of progressive social forces, the conditions in which workers live (with or without employment) as well as other subaltern populations.

Key words: critical Social Work, ethicalpolitical project, Social Work and neoliberalism.

\section{Carlos Montaño}

Doutor em Serviço Social.

Professor e investigador da Universidade Federal do Rio de Janeiro - UFRJ.

Documento original apresentado no Fórum de Debate La profesionalización del Trabajo Social en el siglo XXI: rupturas y continuidades - de la Reconceptualización al proyecto ÉticoPolítico, no marco do Encuentro Latinoamericano de Trabajo Social. Universidad Nacional de La Plata, Argentina, 25 a 27 de agosto de 2005.

Tradução de Santo Gabriel Vaccaro do original Un proyecto para el Servicio Social crítico. 


\section{0 capital e sua crise: inflexões nas políticas sociais e no Serviço Social}

\subsection{0 capital, as políticas sociais e o Serviço Social}

com o desenvolvimento do capitalismo monopolista, sua expansão produtivo-comercial consolidada após a Segunda Guerra (1945) e com as lutas de classes, que surge e se expande um padrão de resposta às manifestações da "questão social", fundamentalmente mediante a intervenção das políticas sociais estatais ${ }^{1}$. No marco destas, cria-se um espaço socioocupacional que será parcialmente ocupado por uma emergente profissão, o Serviço Social ${ }^{2}$. Este surgimento da profissão muitas vezes foi confundido com a evolução das "formas não-profissionais de ajuda" para sua "profissionalização"3. Na verdade, a profissão de Serviço Social surge e se expande embrionariamente vinculada ao surgimento e à expansão das políticas sociais estatais. Estas últimas constituem-se, assim, na "base de sustentação funcional-ocupacional" da profissão ${ }^{4}$. O assistente social surge como implementador das políticas sociais; dessa forma, o que sucede com estas, atinge e afeta aquele.

Assim, as políticas sociais constituem instrumentos de intervenção estatal funcionais ao então projeto hegemônico do capital (produtivo), embora tensa e contraditoriamente representem conquistas das classes trabalhadoras e subalternas. Direitos conquistados para ter certas necessidades atendidas pelo Estado, o que por sua vez significa que o status quo e a acumulação capitalista permanecem inalterados.

O sentido social das políticas sociais (sua função de reprodução do sistema socioeconômico e político e do status quo) e sua tensão e contradição internas (constituir direitos conquistados pelas classes subalternas) são transferidos para aqueles atores que com elas trabalham: os assistentes sociais. Estes passam a ter, em sua prática, o sentido social das políticas sociais. Com isto, aparece uma primeira determinação da prática profissional:

o Serviço Social constitui (a partir de sua vinculação embrionária com as políticas sociais) uma engrenagem na reprodução das relações sociais e do sistema dominante; sua prática social resulta funcional à manutenção da ordem social e às relações capitalistas (a exploração do trabalho, o controle social, a diminuição das lutas sociais e a acumulação de capital).

Mas esta afirmação não pode ignorar as outras duas determinações desta prática:

o Serviço Social desenvolve sua intervenção em um espaço de tensão e contradição entre sua função de reprodução do sistema (a partir dos inte- resses hegemônicos do grande capital) e sua defesa dos direitos e conquistas sociais (a partir de demandas e de lutas das classes trabalhadoras e subalternas); isto reflete uma prática profissional que é essencialmente politica, inserida no interior das contradições entre as classes, ocupando um espaço de disputa de interesses ${ }^{5}$;

o Serviço Social, condicionado pelas estruturas sociais e pelas demandas institucionais (geralmente representantes dos interesses hegemônicos), ainda assim pode apresentar um certo protagonismo e uma margem de manobra relativa ao orientar sua ação profissional; na medida em que dirige seu processo de formação não meramente para o atendimento direto das demandas institucionais, mas formando um profissional crítico e competente, que organize o coletivo em entidades fortes e representativas e que consolide códigos de ética claramente orientados em certos valores definidos coletivamente, $\mathrm{o}$ assistente social pode ver reforçada sua margem de manobra para uma prática profissional que, sem eliminar os condicionantes sistêmicos, privilegie a garantia dos direitos sociais conquistados.

Logicamente esta última determinação da prática profissional só pode ter fundamento a partir da existência de um projeto profissional com suas dimensões ética e política, construído coletivamente, que reforce este protagonismo relativo do corpo profissional. Sem isso, deriva-se inevitavelmente no "messianismo" das vontades e opções individuais ou no "fatalismo" que reside na resignação a respeito dos condicionantes sistêmicos.

\subsection{A crise do capital e a resposta neoliberal}

É consenso entre os intelectuais que o sistema capitalista, após quase 30 anos de clara expansão econômica (1945-1973), ingressa em uma profunda crise: do seu padrão de produção (fordista), do seu sistema de regulação (keynesiano), do seu Estado (de Bem-Estar Social), do tipo de trabalhador (especializado), da sua racionalidade (positivista), crise fiscal, do padrão dólar, das fontes energéticas (petróleo), do subconsumo. Na realidade, o que se observa hoje é uma crise geral, sistêmica.

Diante de tal fenômeno, a fração da classe hegemônica (o grande capital financeiro) aliada aos capitais nacionais desenvolve uma nova forma de enfrentar a crise, por um lado ampliando a exploração do trabalhador e, por outro, subjugando os pequenos e médios capitais. Surge assim, posteriormente a um surto de ditaduras militares, a nova resposta do capital à crise: o projeto neoliberal. A programática neoliberal representa, portanto, a atual estratégia hegemônica de reestruturação geral do capital (que para a América Latina segue o receituário do Consenso de Washington, de 1989) frente à crise e às lutas de classes, e que 
deriva basicamente em três frentes articuladas: o combate ao trabalho (às leis e políticas trabalhistas e às lutas sindicais e da esquerda) e as chamadas "reestruturação produtiva" e "(contra-)reforma do Estado".

\subsection{Repercussões nas conquistas das classes subalternas e no Serviço Social}

Nesse sentido, dadas as substanciais transformações no mundo do trabalho, de tal forma a afetar a realidade das classes trabalhadoras, principais usuárias das políticas sociais, e dadas as alterações desenvolvidas no âmbito dos Estados nacionais, organismos responsáveis, por excelência, pelas respostas às refrações da "questão social", sendo as políticas sociais mediações entre o Estado e as classes sociais, pode-se então afirmar que, conseqüentemente, as políticas sociais no atual contexto neoliberal são substancialmente alteradas em suas orientações e em sua funcionalidade.

Como solução parcial à crise capitalista, o neoliberalismo pretende a reconstituição do mercado livre, reduzindo e inclusive eliminando a intervenção social do Estado em diversas áreas e atividades. Assim, nessa nova estratégia hegemônica (neoliberal) do grande capital, é concebido um novo tratamento à "questão social". Cria-se uma modalidade polimórfica de respostas às necessidades individuais, diferentes conforme o poder aquisitivo de cada pessoa. Portanto, tais respostas não constituiriam um direito, mas uma atividade filantrópica/voluntária ou um serviço comercializável; também a qualidade dos serviços responde ao poder aquisitivo da pessoa; a universalização cede lugar à focalização e à municipalização; a "solidariedade social" passa a ser localizada, pontual, identificada com a auto-ajuda e com a ajuda-mútua.

É assim que, no que concerne ao novo tratamento da "questão social", a orientação das políticas sociais estatais é alterada de forma significativa. Elas são privatizadas, transferidas ao mercado e/ou inseridas na sociedade civil; por sua vez, contra o princípio universalista e de direito de cidadania, são focalizadas, isto é, dirigidas exclusivamente aos setores portadores de necessidades pontuais, o que permite sua precarização; finalmente, elas são também descentralizadas administrativamente, levando as regiões pobres a ter que se contentar com a administração de recursos insuficientes para suas respostas sociais ${ }^{7}$.

Com isto ocorrem, por um lado, claras perdas de direitos conquistados pelos trabalhadores e setores subalternos da sociedade, particularmente em relação às já precárias estruturas de atenção, assistência e segurança social. Passa-se da política social e da assistência social como um direito do cidadão (garantido pela ação estatal) para a ação voluntária, filantrópica, assistencialista, clientelista (desenvolvida no âmbito das organizações e pelos indivíduos da sociedade civil).

Por outro lado, observam-se inflexões na profissão repercutindo significativamente em pelo menos três níveis: 1) em sua condição de trabalhador - aumentando o desemprego profissional, precarizando o vínculo trabalhista, levando a uma tendência à "desprofissionalização"; 2) em sua demanda direta e indireta - aumentando e diversificando as manifestações da "questão social" enfrentadas pelo assistente; e 3) em sua prática de campo - reduzindo os recursos para implementar serviços sociais; demandando o "tarefismo" ou o "ativismo" que subordina a qualidade do atendimento à quantidade; com a "desuniversalização" das políticas sociais, atuando o assistente social em micro-espaços; com tendência à "filantropização" e ao "assistencialismo" e, inclusive, à "mercantilização" dos serviços sociais (retirando-lhes a dimensão de direito de cidadania).

\section{A necessidade de uma resposta profis- sional progressista, crítica, comprometida e competente}

É assim que a situação atual desafia a profissão a enfrentar estas inflexões e construir respostas coletivamente. Claro que as possibilidades de concretização destes desafios profissionais não são alheias às tendências sociais e às correlações de forças existentes.

\subsection{Projetos societários e projetos profis- sionais}

Atualmente, é possível identificar a disputa de, pelo menos, três grandes projetos de sociedade: a) o projeto neoliberal (de inspiração monetarista, sob o comando do capital financeiro, que procura, no atual contexto de crise, desmontar os direitos trabalhistas, políticos e sociais historicamente conquistados pelos trabalhadores, acentuando a exploração de quem vive do trabalho e sugando os pequenos e os médios capitais); b) o projeto reformista (tanto em sua vertente liberal-keynesiana como social-democrata, 
representando o expansionismo do capitalismo produtivo/ comercial conjuntamente com algum grau de desenvolvimento dos direitos civis, políticos, sociais e trabalhistas) e c) o projeto revolucionário (fundamentalmente de inspiração marxista que busca, gradual ou abruptamente, a substituição da ordem capitalista por uma sociedade sem classes, sem exploração e regida pelo trabalho emancipado).

Destes projetos se desprendem diversos valores e princípios $^{8}$ que orientam comportamentos e valores profissionais. Em termos gerais, pode se constatar hoje um certo ecleticismo profissional no sentido de reunir componentes dos diversos projetos sociais (com seus valores e princípios antagônicos). Quando isto ocorre, fica comprometida qualquer tentativa de construção de um projeto éticopolítico profissional realmente progressista; o resultado é um mosaico de partes constitutivas de tais projetos reunidas acriticamente, o que acaba por reforçar o projeto hegemônico da classe dominante. Isto leva à necessidade de explicitar características de um novo projeto ético-político profissional capaz de fazer frente ao contexto neoliberal, tal como se pretende construir.

\subsection{0 projeto ético-político profissional: um projeto em processo de construção coletiva}

Assim, toda ação que procure enfrentar e reverter as atuais tendências neoliberais deve partir das seguintes considerações:

Deve ser determinada a partir da construção/consolidação não apenas de ações individuais, mas de um projeto profissional hegemônico que integre e articule as dimensões ética e política. Projeto este construído democraticamente pelo coletivo profissional. Por isso, mais do que um projeto significa um "processo" que está em construção. A polêmica, os debates, as produções teóricas, a correlação de forças internas da profissão, que agrupa tendências e subtendências, tudo isso constitui o processo de construção de um projeto ético-político profissional.

Porém, o pluralismo e o consenso não substituem a necessidade de constituir maiorias, construção democrática e plural, sem prescindir de uma clara direção social legítima. Pluralismo e respeito às minorias não eliminam a legítima hegemonia da maioria, não equivalem à soma das partes, da mesma forma como consenso não equivale à ausência de dissensos; aquele se constrói a partir da articulação (dada a partir de determinada correlação de forças) destes, superando-se assim os vazios "consensos do óbvio" - ou seja, aqueles acordos aceitos por todas as tendências, que de tão "lavadas", são esvaziadas de seus conteúdos essenciais, como declarações de "combate à pobreza", etc.
Um projeto profissional não é algo isolado, mas necessariamente inspirado em e articulado com projetos societários. Portanto, o projeto profissional importa, redimensiona e se insere em determinados valores, ideologias, projetos, articulado com atores sociais que representam os valores, ideologias e projetos profissionais hegemônicos. Além disso, os projetos profissionais não só se inserem em projetos e valores sociais mas estão, de alguma maneira, condicionados pelo lugar que ocupam na correlação de forças na sociedade.

Um projeto profissional, se legítimo e plural, mesmo que articulado com uma determinada correlação de forças internas, desdobra-se em um projeto de formação profissional, em um código de ética, em uma organização acadêmica elou corporativa profissional, que estabelecem relações e interlocução com atores sociais em função da articulação de seus valores e projetos.

Considerando a "questão social" , as lutas de classes e as desiguais condições de vida, a partir da relação de exploração entre capital e trabalhadores, logicamente um projeto ético-político profissional deve ser sensivel aos interesses das classes trabalhadoras e às populações mais desfavorecidas. Os interesses das classes trabalhadoras e dos grupos subalternizados devem permear um projeto como tal.

\subsection{Fundamentos do projeto profissional crítico e progressista a partir das perspectivas histórico-críticas}

Torna-se assim necessária a clara caracterização e construção de um projeto profissional crítico e progressista a partir de "tendências histórico-críticas", fundado em princípios e valores tais como: a liberdade (não só formal, negativa, mas que considere a potencialidade), a democracia substantiva (e a democratização); a cidadania e sua expansão, ampliando os direitos humanos, civis, políticos e sociais; a justiça social (e a igualdade social, que não se confundem com a identidade); as politicas sociais universais, não-contributivas, de qualidade e constitutivas de direito de cidadania; a ampliação da esfera pública; a eliminação de toda forma de exploração, dominação e submissão como sistema de convivência social e de desenvolvimento de uma essencial cidadania e da emancipação humana.

O fato do assistente social estar no contexto das contradições e dos conflitos entre classes (o que não significa que possua um papel "mediador" entre elas) faz deste profissional, particularmente, um ator essencialmente político. Político (não partidário) no sentido de participante desta relação conflituosa entre as classes. Relação (onde atua o assistente social) que se expressa de várias 
formas: déficit de consumo, incapacidade de acesso a determinados bens e/ou serviços, questões salariais, desemprego, discriminação (de todas as formas: sexual, de gênero, étnica e racial, xenofobia, etária, etc.), mortalidade, dependência química, entre tantas outras manifestações da "questão social". Nesse sentido, a falta de visão de tal situação certamente vem para reforçar (inclusive de forma inconsciente) a situação existente e os interesses das classes dominantes (que direta ou indiretamente se apresentam como empregadoras do profissional). Faz-se necessário, então, tornar explícito o compromisso ético-político através da defesa dos valores do trabalho - trabalho emancipado do capital, contra a exploração e a dominação do homem sobre o homem - e da defesa dos direitos historicamente conquistados pelas classes trabalhadoras e pelos setores subalternos - direitos trabalhistas, sociais, políticos e de cidadania.

Isso significa o comprometimento do assistente social em centrar sua ação profissional nesses valores, o que supõe um claro corpo ético-político (Códigos de Ética) que oriente e controle o exercício profissional a partir dos consensos criados pelos coletivos profissionais e da articulação com outros atores institucionais e sociais, objetivando reforçar seu papel na correlação de forças existente.

\section{0 debate de idéias no interior da profissão}

A partir destas propostas - que têm por objetivo contribuir com um processo coletivo de criação de um projeto ético-político profissional, crítico, competente e comprometido com os valores já enunciados, dotando o profissional daquele relativo protagonismo dentro das determinantes estruturais no campo tenso e contraditório que enquadra a prática profissional -, começam a surgir contestações e enfrentamentos ${ }^{10}$. Mas, poderiam entender-se estas contestações como uma crítica à crítica do Serviço Social (ou a um Serviço Social crítico)?

Para começar, o conceito de crítica aceita duas acepções bem diferentes. Primeiramente, crítica como busca da verdade, confrontando a teoria com a realidade (com a prática social) ${ }^{11}$. Neste caso, o objetivo da crítica é a fiel reprodução teórica da realidade; a verdade, que existe na realidade material, deve ser corretamente refletida na teoria. Um postulado teórico é verdadeiro ou falso não por sua "aplicabilidade" a uma realidade singular, não pela "adequação" a este ou aquele método considerado científico, mas por sua fidelidade ao objeto em questão. Crítica aqui significa busca da verdade, tendo a realidade como critério de veracidade e a teoria (crítica) como fiel reflexo daquela.

Diferentemente, o segundo significado de crítica (talvez o mais utilizado no cotidiano) remete à ação de julgar desfavoravelmente, censurar ou rechaçar algo: criticar algo. Neste caso, o marco referencial para avaliar um postulado ou um objeto não é o contraste com a realidade, mas a subjetividade dos juízos de valor de um indivíduo. Quando se rechaça algo, critica-se a partir de um juízo de valor.

A reflexão crítica do Serviço Social (ou a busca de um Serviço Social crítico) sustenta-se nas teorias críticas (aquelas que buscam a verdade a partir do reflexo teórico apropriado da realidade) sobre a estrutura e as dinâmicas sociais. É contra esta reflexão (crítica) que se desenvolve uma crítica, com sentido de rechaço, censura, juízo de valor. É nesse último sentido que textos/autores "contestadores" serão referidos, não como críticos, mas como críticas.

\subsection{As diversas manifestações de "contes- tação" ao projeto ético-político crítico e progressista e às "perspectivas histórico- críticas": seus argumentos centrais}

Efetivamente, durante quase duas décadas, o Serviço Social na América Latina sofreu uma espécie de imobilismo intelectual. Pouco debate, pouca polêmica, pouco enfrentamento de idéias. Como se todos pensassem igual, como se todas as contribuições fossem confluentes. Entre outras coisas, isto se devia à ênfase metodologista que imperava na produção acadêmica e nas preocupações com as práticas singulares, assim como a quase ausência de produção teórica mais recente.

A saída à luz de novas análises sociais no novo contexto neoliberal, de novas reflexões sobre o papel social da profissão, partindo de categorias e conceitos centrados na emancipação do trabalho, na plena cidadania, tendo como referenciais teóricos autores, clássicos ou não, de sólido fundamento dialético e crítico, tudo isso mobilizou novas e velhas adormecidas energias e polêmicas. Amplos setores do coletivo profissional "contagiaram-se" com esta nova onda de debate crítico e comprometido ${ }^{12}$, com estes novos questionamentos e considerações que tentavam entender de forma diferente questões centrais para a profissão que até então não haviam encontrado respostas satisfatórias.

O simples fato de despertar o adormecido espírito de estabelecer polêmica entre idéias no interior de nossa profissão já constitui um elemento extremamente positivo deste novo debate.

Não obstante, nada consistente reúne unanimidade de opiniões na história humana. Assim surge a reação e o enfrentamento, contestando e/ou rejeitando a tentativa de incentivar a construção de um projeto ético-político, crítico e comprometido. Não sem um grande número de significativos equívocos de interpretação (cuja análise de conjunto seria tediosa e desnecessária), essa "contestação", recolhida nos textos já relacionados, apresenta os seguintes argumentos: 
a) considera que as análises histórico-críticas desqualificam a imagem do Serviço Social, contribuindo para seu desprestigio social;

b) concebe as diversas contribuições histórico-críticas como homogêneas, atribuindo-lhes uma suposta perspectiva brasileira;

c) parte da ilusão sobre a possibilidade de autodeterminação do sentido da prática profissional, a partir da mera vontade e de opções individuais;

d) caracteriza como funções profissionais centrais a mediação de conflitos e a integração social;

e) prioriza as micro-experiências como caminho para a solução de "problemas" ou conflitos singulares e locais, deixando em segundo plano as conquistas estruturais e universais e as lutas centrais;

f) o imediato, o emergente, ocupa lugar central, hipotecando qualquer projeto de médio ou longo prazo;

g) promove um retorno aos autores tradicionais do Serviço Social, descartando as reflexões críticas e superadoras dos mesmos;

h) apresenta uma explícita ou implícita rejeição à reconceptualização e identifica sumariamente as propostas de construção coletiva de um projeto ético-político profissional com aquele movimento;

i) em alguns textos "contestadores" aparece visivelmente uma tendência anti ou pós-marxista, entendendo que a proposta de construção de um projeto ético-político se esgotaria nesta perspectiva;

j) finalmente, percebe-se uma clara negação e rejeição ao debate acadêmico responsável e explícito, através da desqualificação e tergiversação de seus interlocutores.

\subsection{Crítica à "crítica crítica": abrem-se a polêmica e o debate interno}

A seguir são enumerados os argumentos centrais expressos nestas contestações, assim como a nossa reflexão crítica de seus conteúdos.

(I) A consideração de que a análise crítica "desqualifica" a imagem do Serviço Social, contribuindo para seu desprestígio.

Esta constitui a hipótese central esgrimida pelos contestadores das "perspectivas histórico-críticas". Consiste na idéia de que a análise crítica, consolidada na história social capitalista, particularmente na América Latina, à medida que constata certa função de reprodução do sistema e do status quo, estaria contribuindo para desprestigiar e desqualificar a imagem da profissão. Estas são algumas afirmações ${ }^{13}$ :

Com a energia e o zelo de um inquisidor medieval, Iamamoto se lançou em 1992 a levar a processo ao
Trabalho Social, acusando-o de profissão originada numa herança conservadora católica que, levada depois ao campo secular, tecnificada e modernizada, teria mantido no entanto as 'manchas' de sua espúria origem intocadas, dentro de 'um cunho conservador-reformista' [...] esta 'diabolização' do Trabalho Social presente em muitos autores da última década se inscreve numa interpretação fortemente niilista, substanciada pela chamada 'desilusão respeito do socialismo real' (PORZECANSKI, 2001, p. 75, grifo nosso).

Se tivéssemos que caracterizar os inimigos do Serviço Social, encontrar-nos-íamos com três tipos principais, dois externos e um interno à profissão [...] c) o inimigo interno ao que nos referimos não o parece a primeira vista, pois usa uma linguagem parecida à de todos no conjunto profissional e freqüentemente se dirige aos colegas com aparentes intenções construtivas. $\mathrm{Na}$ realidade se convertem em destruidores do Serviço Social, antes por não conseguir compreendê-lo, mesmo que em alguns casos possam fazê-lo por oportunismo ideológico [...] Assim vemos no prólogo de um texto muito recente de Carlos Montaño [...] (DI CARLO, 2001, p. 20, grifo nosso). [...] debater os supostos básicos constitutivos especificos do trabalho social profissional, com outras correntes de interpretação, que no nosso entendimento entendem mal esta profissão e em conseqüencia terminam atacando-o com a intenção, ou confusão, de modificá-la na sua razão de ser (DI CARLO, 2004, p. 7, grifo nosso).

A repercussão destas tendências na formação profissional [...] Atenta contra a identidade profissional e contra seu desenvolvimento, da mesma forma que o fez há umas décadas a chamada etapa de 'reconceituação', a qual freou durante anos o desenvolvimento da profissão (CORTINAS, 2003, p. 28). Faz pouco tempo expressei [...] minha preocupação pelas tendências detratoras manifestadas na literatura contemporânea sobre o Serviço Social Profissional (SSP) e sobre o perigo que elas ocasionavam ao influir fortemente nos vastos setores da profissão. Da leitura do livro 'Capitalismo Monopolista e Serviço Social', cujo autor é o Professor José Paulo Netto, surgem nitidamente grandes discordâncias de suas afirmações e reforçam a expressada preocupação. Este livro se propõe demonstrar o caráter conservador e reacionário dos Serviços Sociais, tanto no institucional como no profissional. Produto do desenvolvimento capitalista, seu destino [do 
Trabalho Social] é acunhá-lo, servi-lo [...] Estas origens marcam sua substanciação, a especificidade conservadora ou reacionária da profissão. A legitimação [da profissão] [...] contém sempre o pecado original da filantropia, ao serviço da classe burguesa, dentro do sistema capitalista. Netto acusa de sincretismo o Serviço Social [...]. A obsessão que manifesta pela reprodução da sociedade [...] o conduz a tomar uma atitude detratora para com os $S$. S. institucionais e seus agentes, os profissionais, pela sua ação a favor dos interesses burgueses (CORTINAS, 2003a, p. 17, 18, 23, grifo nosso).

Na nossa profissão existe uma polêmica mais de corte ideológico do que científico, na qual certo setor de trabalhadoras e trabalhadores sociais afirmam que se trata de uma profissão criada pelas classes dominantes para contribuir a manter o status quo social [...] Na verdade é o momento para que, no lugar de fazer afirmações de ruptura com a profissão de trabalho social, façam um esforço por contribuir a que o labor profissional seja realizado cada vez com maior eficácia e com melhores condições institucionais [...] Seguir pelo caminho de afirmações desintegradoras unicamente confirma o perigo da ideologização [...] (SAN GIÁCOMO, in DI CARLO, 2004, p. 88,89-97, grifo nosso).

É interessante esta preocupação com um suposto "ataque" à profissão, partindo de seus supostos "inimigos internos" ao, supostamente, "diabolizar" o Serviço Social, "acusando-o" de reacionário e servil aos interesses do capital.

Será que a diferença entre uma "acusação" e uma análise histórica não é percebida? É possivel discrepar das análises históricas feitas pelos autores das "perspectivas histórico-críticas", mas resulta sintomático que estas sejam rotuladas e consideradas como "acusações" que desqualificam a imagem profissional. Como deveria proceder um intelectual cuja análise histórica sobre a inserção do Serviço Social no capitalismo monopolista revela uma certa funcionalidade (funcionalidade em nítida tensão com as orientações ético-políticas individuais e coletivas dos assistentes sociais) da profissão a serviço da reprodução do sistema e do status quo? Deveria negar os resultados da investigação e da história para não "atacar a imagem profissional"? Deveria criar uma imagem "positiva" da profissão, ainda que historicamente infundada e falsa?

Em uma perspectiva claramente diferente da tradição marxista, Michel Foucault analisa o desenvolvimento da medicalização como parte de um projeto de controle, de poder social dos setores dominantes sobre a população. Para Foucault, (1985, p. 95),
[...] a partir do momento em que o pobre se beneficia do sistema de assistência deve, por isso mesmo, submeter-se a vários controles médicos. Com a Lei dos pobres aparece, de forma ambigua, algo importante na história da medicina social: a idéia de uma assistência controlada, de uma intervenção médica que tanto é uma maneira de ajudar os mais pobres[...] como um controle através do qual as classes ricas ou seus representantes no governo asseguram a saúde das classes pobres e, por conseguinte, a proteção das classes ricas.

Deve-se considerar as análises foucaultianas como um "ataque" ao médico ou à medicina? É este autor um "inquisidor medieval" do profissional da saúde? É este um "inimigo interno" da instituição hospitalar?

Parece, então, que "amoldar" a imagem da realidade aos desejos não deveria fazer parte do horizonte intelectual. Se a análise da história exibe a tensão existente na prática profissional do Serviço Social - por um lado forjada na função social que as políticas sociais transferem à profissão (estas como parte de estratégias capitalistas, ainda que permeadas por demandas das classes subalternas), e por outro, no relativo protagonismo profissional para reconduzir sua formação e ação -, este fato não deve ser escondido ou rejeitado com a finalidade de não "ferir" uma imagem profissional que se considera ideal. O compromisso com a verdade deve ser superior à necessidade corporativa de dotar a profissão da imagem desejada. Além disso, a possibilidade de um relativo protagonismo profissional (que não elimina completamente os determinantes sistêmicos) para orientar esta prática no sentido de reforçar direitos conquistados por trabalhadores e cidadãos, em geral só encontra terreno fértil na análise crítica da realidade histórica, que determina a particularidade da profissão do Serviço Social.

Por outro lado, resulta claramente endogenista (voltarse-á a isto) pensar que a constatação de que a profissão cumpre um papel particular na reprodução do sistema social (acumulação de capital, manutenção das relações sociais e do status quo) acarretaria automaticamente no suposto caráter "conservador" de seus membros; ou supor que este papel pode ser revertido pelo posicionamento "progressista" dos mesmos. O caráter funcional da profissão (ainda que tenso e complexo) depende mais dos determinantes estruturais e da correlação de forças e dinâmicas sociais do que das opções de seus membros (sejam estes "conservadores" ou não). Uma coisa é conceber o papel do Serviço Social na reprodução da ordem dominante, outra é supor que o indivíduo é quem é conservador. Este equívoco é extremamente comum na profissão, o que levou, algumas vezes, a se atribuir um caráter necessariamente conservador aos assistentes sociais de outrora (os precursores) ou a se considerar o 
assistente social como "agente de transformação". Nem necessariamente "conservador" nem "agente de transformação". O papel, o sentido social da profissão, depende mais dos resultados das lutas de classes, dos projetos societários em discussão e da estratégia hegemônica, do que das concepções e opções dos seus membros.

(II) $\mathrm{O}$ apelo nacionalista, ao homogeneizar as considerações críticas através da expressão "perspectiva brasileira".

Os contestadores das "perspectivas histórico-críticas" realizam uma homogeneização imprópria, identificando estas perspectivas (por si heterogêneas) com uma instituição (a UFRJ ou a PUC-SP) ${ }^{14}$ ou com uma nação (Brasil) ${ }^{15}$.

Primeiramente, deve-se registrar a heterogeneidade destas "perspectivas histórico-críticas", incorporando concepções e tendências variadas da tradição marxista (Marx, Lukács, Gramsci, Mandel, dentre outros), correntes neo-kantianas (pela via, por exemplo, de Habermas), tendências pós-modernas (recorrendo a Boaventura de Sousa Santos e outros), elaborações do pensamento liberal ("cidadania", "pluralismo", "Estado de Bem-Estar Social", etc.). Para seus contestadores, esta heterogeneidade se desvanece e se reduz a um pensamento supostamente homogêneo.

Em segundo lugar, é necessário mostrar que nem a Universidade Federal de Rio de Janeiro (UFRJ) nem a Pontifícia Universidade Católica de São Paulo (PUC-SP) podem ser consideradas internamente como homogêneas. Muito menos reduzir ambas instituições a um pensamento supostamente uniforme. Objetos de estudo e perspectivas de análise são vários e diversificados em ambas instituições.

Em terceiro lugar, e a partir de um claro desconhecimento do debate profissional brasileiro, é equivocado supor que este seja homogêneo, sem polêmicas, dominando por uma tendência específica. $O$ processo de construção de um projeto profissional no Brasil não prescindiu nem prescinde de um árduo, rico e polêmico debate de idéias. $\mathrm{Na}$ verdade, existem autores e tendências variadas no Brasil (como em qualquer contexto) que se expressam com absoluto respeito e liberdade, processando suas diferenças nos foros profissionais e estabelecendo negociações e deliberações nos organismos profissionais correspondentes.

O que se constata então, nesta homogeneização, é um verdadeiro apelo nacionalista. A idéia de que a polêmica esteja apresentada entre nações não tem fundamento. Algo como um suposto "imperialismo brasileiro" colonizando os demais países latino-americanos. Mesmo conhecendo o papel que o governo brasileiro desempenha na região (ver, por exemplo, os conflitos de interesses no Mercosul ou o caso do gás boliviano com a Petrobrás) não se pode confundir governos com suas populações, muito menos com os processos e tendências de um heterogêneo coletivo profissional. As relações entre governos nacionais pouco re- presentam as relações entre os povos desses países. Mas aqui não se está falando de governos, e sim de debates profissionais, de perspectivas teórico-metodológicas e ético-políticas, enfim, de projetos profissionais.

Se assim fosse, se as "perspectivas histórico-críticas" fossem identificadas com o Brasil, seria então legítimo pensar seus contestadores como a "perspectiva uruguaia"? Nesse suposto caso, dever-se-ia pensar em uma "disputa entre nações"? Este apelo nacionalista logicamente constitui uma forma de escamotear ou driblar o verdadeiro fundamento da polêmica: não se trata de um enfrentamento entre nações, mas de um debate entre perspectivas teórico-metodológicas e tendências ideológico-políticas que redundam em diferentes projetos profissionais. Tendências "histórico-críticas" - comprometidas com a garantia e o desenvolvimento de direitos civis, trabalhistas e sociais, com políticas sociais universais e constitutivas de direito cidadão, com a justiça social e a liberdade, com o aprofundamento da democracia, com a emancipação do trabalho e do homem (perspectivas que vão desde a socialdemocracia até as socialistas) e inclusive, em alguns casos, tendo como horizonte a superação do sistema de exploração e de classes; e tendências "endogenistas" - que valorizam a filantropia, a benemerência, assim como valores abstratos como o "bem-comum" e a "conciliação entre classes" (a exemplo das Encíclicas Rerun Novarum e Quadragesimo Anno), que aceitam como inalterável o sistema social imperante (perspectivas antimarxistas, tocquevillianas, neoliberais, pós-modernas, etc.). Tendências estas impossíveis de serem divididas entre nações, mas presentes no interior de cada país.

Aqui o que divide "fronteiras" não são os limites nacionais, mas as divergências entre projetos sociais $e$ profissionais, entre perspectivas teóricometodológicas. E estas divergências existem em todos os países. A "oposição entre nações" tem o evidente objetivo de esconder a real polêmica, apelando ao nacionalismo e ocultando o debate entre ideologias, perspectivas teórico-metodológicas e projetos profissionais. O capital é internacional, portanto, a articulação entre cidadãos, trabalhadores, intelectuais, profissionais, etc, que defendem as conquistas históricas das classes subalternas e que vislumbram uma nova sociedade sem classes e sem exploração, esta articulação, apesar de organizar-se em primeira instância nos espaços nacionais, deve alcançar uma dimensão internacional.

Aqui se observa também outro aspecto colateral: o descrédito no protagonismo das instituições e nos colegas de outros espaços institucionais e de outras nações. Como menciona Porzecanski (2001, p. 77) "A linha interpretativa da UFRJ tem influído, no entanto, nas questões disciplinares no Uruguai $[\ldots .$. ]". Em sua concepção, não seriam os colegas uruguaios que internamente, a partir de seu debate acadêmico e profissional e de sua correlação de forças internas (no 
que se refere a temáticas e perspectivas), tomam decisões conscientes, que podem ser confluentes com alguns posicionamentos de colegas de outros países. Esta autora parece entender o contrário, que se trataria da influência externa que coloniza alguns ingênuos e desprotegidos profissionais uruguaios, como se afirmasse: "perdoa-os, não sabem o que fazem!'”. O mesmo ocorre quando se atribui influência da PUC-SP no meio profissional argentino ${ }^{17}$.

(III) O "endogenismo" analítico, a "naturalização" da profissão e o "messianismo" existentes na ilusão da autodeterminação do sentido da prática profissional.

Os textos contestadores das "perspectivas históricocríticas" apresentam fortes e explícitas tendências "endogenistas", ou seja, a perspectiva de análise que aborda os fenômenos (neste caso a profissão) meramente a partir de seus elementos internos, sem considerá-los como resultado de processos históricos mais amplos. No caso do Serviço Social, a abordagem endogenista considera como atores/sujeitos os seus próprios profissionais (não as classes sociais, o Estado, a mulher como sujeitos coletivos); os fenômenos que desencadearam o surgimento da profissão são assim determinados a partir de movimentos internos à prática da assistência e da ajuda (e não a partir da passagem do capitalismo concorrencial para o monopolismo, do projeto hegemônico do capital, do surgimento de um "Estado de Bem-Estar Social" ou das conquistas de lutas de classes); a legitimidade profissional estaria dada então por sua "especificidade" (e não pelo espaço ocupacional e funcional criado pelas políticas sociais dentro de um contexto histórico determinado), etc. ${ }^{18}$.

Neste flagrante endogenismo, pensa-se - equivocadamente - que a constatação do papel social da profissão significaria, conseqüentemente, uma "acusação", a cada assistente social, de ser "conservador"; um raciocínio formal e pobre no sentido de: "se a profissão é funcional ao sistema imperante é porque seus membros são conservadores". Da mesma forma, para romper com este "estigma" da profissão seria suficiente a opção individual do profissional; algo assim como: "o profissional 'conservador' terá um desempenho reprodutor do status quo, enquanto o assistente social 'progressista' desenvolverá uma prática transformadora". Assim, para que a profissão tenha uma função progressista basta que os assistentes sociais sejam progressistas; chega-se, então, à constação de que o papel funcional da profissão com a reprodução da ordem estaria afirmando o caráter conservador dos seus membros.

Este silogismo formal não reflete a realidade nem o pensamento dos autores das "perspectivas histórico-críticas". $\mathrm{Na}$ realidade, nestas correntes entende-se que o papel social do Serviço Social (na reprodução do social e do status quo) está fortemente condicionado pela estrutura e pelas dinâmicas sociais, expressas fundamentalmente pela correlação de forças e pelas lutas de classes.
Assim, um Projeto Profissional tem a intencionalidade de, sem pretender desconhecer as determinações sociais da profissão, dotar o Serviço Social de um protagonismo maior, de forma a ampliar o espaço de sua legitimidade em direção à ação que confirme e amplie os direitos sociais e as conquistas populares. Se o assistente social, individualmente e a partir de suas opções pessoais, não determina o sentido de sua prática (condicionada pelos determinantes macrossociais), o coletivo profissional, organizado conjuntamente em torno de um projeto profissional ético-político (determinando sua formação, seus temas de estudo e investigação, seu código de ética, suas normas institucionais, etc.), poderá ampliar em algum grau seu protagonismo na determinação parcial do sentido social de sua ação.

Assim, numa perspectiva endogenista, a crise de legitimidade profissional não seria obra da crise social e sistêmica, que repercute na estrutura de proteção social e nos direitos conquistados, comprimindo (focalizando e precarizando) as políticas sociais estatais. Ela seria o resultado do "ataque" de certos "inimigos internos" que "julgam o Serviço Social" $"$.

Mas tal perspectiva endogenista freqüentemente acompanha um processo de "naturalização" da profissão em suas funções, "missões", objetivos, etc. São alguns exemplos disto:

O Trabalho Social ocupa um lugar natural ao lado das classes que lutam e consagram conquistas sociais [...] (CORTINAS, 2003, p. 32, grifo nosso).

Nesta luta de contrários é obvio que o compromisso do Trabalho Social estará sempre do lado da defesa do humano [sic] (CORTINAS, 2003, p. 33, grifo nosso).

[...] o Trabalho Social tem como missão buscar a integração social e moral do indivíduo à sociedade para seu próprio bem (DI CARLO, 2004, p. 12, grifo nosso).

O problema não é somente teórico, em termos de perspectiva. A naturalização destas questões acaba colocandoas como dados ahistóricos, inalteráveis e, portanto, seus postulados operam como verdadeiros axiomas (naturais). Neste processo, o tão buscado debate coletivo sobre qual deve ser "a missão" da nossa profissão, sobre quais devem ser seus "compromissos ético-políticos", passa a ser substituído por estes axiomas elaborados no escritório de algum intelectual que assim o determinou. Ao invés do corpo profissional debater e fundamentar as diversas posturas sobre estes temas para formular um "Projeto Ético-Político Profissional" a partir do consenso gerado, reconhecendo as orientações das maiorias, o debate seria substituído pelo axioma; "o projeto profissional" elaborado a partir do deba- 
te coletivo é substituído pela "missão natural" determinada unilateralmente como "óbvia" por alguém.

Mas esta naturalização muitas vezes conduz a um verdadeiro "fatalismo", ao cristalizar as condições atuais como imutáveis, rígidas, perenes, ingressando assim num possibilismo resignado e hipotecando as possibilidades de um horizonte distinto. Isto é o que se vê em definições como "o trabalho social possível" (DI CARLO, 2004, p. 13).

Outro aspecto que anda junto com o endogenismo e a naturalização dos processos relacionados ao desenvolvimento da profissão é o "messianismo". Tratado por Iamamoto (1997, p. 183 e ss.), o "messianismo utópico" considera como determinantes da prática profissional "as intenções, os propósitos do sujeito profissional individual", promovendo um "voluntarismo" e uma "visão heróica" e "ingênua" da ação do indivíduo. A conseqüência disto é clara: por que um "Projeto Ético-Político" para a profissão, se cada indivíduo determinaria por si mesmo o sentido e a orientação de sua prática profissional?; por que um projeto coletivo se é entendido que a "missão natural" está dada, ou que a mera intencionalidade do indivíduo é suficiente para dar sentido à própria ação profissional? Mais uma vez opta-se pela direção individual ao invés da construção coletiva.

Mas o problema se amplia quando se reconhecem os determinantes externos, alheios à vontade individual de um profissional, ao ver que o sentido de sua prática profissional não está autodeterminado, mas fortemente condicionado pela estrutura e dinâmica social, onde as classes sociais apresentam interesses antagônicos, onde existe nítida hegemonia do grande capital (hoje particularmente do financeiro), etc. A partir de tais constatações (ver as citações anteriores), pensar que seria "natural a localização da profissão ao lado dos mais desfavorecidos" ou que é "óbvio o compromisso com as classes subalternas" é um equívoco teórico com sérias implicações políticas na prática: pensa-se que se está do lado do trabalhador, do "povo", do explorado ou do submergido, por uma suposta condição natural da profissão ou pela mera opção e vontade do indivíduo, mas, na verdade, e sem necessariamente sabê-lo, está-se ocupando um lugar na engrenagem das relações sociais dominantes, onde o capital detém explícita posição hegemônica ${ }^{20}$. A única forma de alterar tal situação é a partir da tomada de consciência do papel social real da profissão e de sua tensão - saturá-lo da contradição entre a funcionalidade sistêmica e a ação que reforça interesses populares e direitos conquistados, politizando a prática profissional ${ }^{21}$.

(IV) Indícios de um pensamento conservador.

Em muitos dos textos contestadores das "perspectivas histórico-críticas" é possível constatar indícios claros de um pensamento conservador. Esta afirmação será fundamentada, sobretudo, por um texto em particular (DI CARLO, 2004).
Em seu artigo, Di Carlo (2004, p. 10, grifo nosso) afirma que os autores da PUC-SP "põem a consciência política do assistente social atuante na realidade sobre as suas responsabilidades como profissional", dissociando desta forma a "consciência política" do assistente social da sua "responsabilidade profissional". É possível pensar a responsabilidade profissional de um sujeito sem que esteja fortemente arraigada em sua consciência política? Segue o autor: "Não é nossa obrigação formar adictos políticos para tendências políticas, credos ou grupos ideológicos" (p. 11), confundindo orientações ético-políticas de um profissional (ou do coletivo) com posturas partidárias (tendências, dogmas, credos). Já Diego Palma mostra como "muitos trabalhadores sociais - movidos por um realismo que abafava toda ilusão - propiciaram, a meados dos anos 70 , um retorno para 'o profissional' [...] como uma atividade claramente distinta do fazer político". Para este autor, “"o profissional' não representa uma atuação objetivamente neutral no conflito das classes; muito pelo contrário, o trabalhador social, nesse projeto, representa uma função importante no processo de enquadramento das classes subordinadas al esquema de dominação" (PALMA, 1985, p. 94).

Mas, se a reconceptualização muitas vezes cometeu o erro de confundir "tarefa profissional" com "tarefa político-partidária" (sem que com esta afirmação se ignore o contexto histórico dos anos 60), por outro lado esse movimento contribuiu em algo fundamental: incluir na agenda do debate profissional a necessidade de politizar (não "partidarizar") a prática profissional, entendendo-a não como um agir neutro e intermediador, mas como uma atividade tensa, política, inserida em um espaço de contradição e de conflito de interesses.

Deve-se ainda manifestar que o pensamento conservador (no Serviço Social) também é politico, também serve a interesses particulares (neste caso, das classes dominantes), só que o negando, escondendo-o ou o ignorando.

A partir desta separação do agir profissional em relação à sua consciência política, com a clara "despolitização profissional", outras conjeturas aparecem para mostrar mais indícios de um pensamento conservador. Afirma Di Carlo (2004, p. 12, grifo nosso): "Em primeiro lugar cabe considerar que a necessidade de viver numa sociedade integra$d a$ é uma necessidade humana universal", sendo que "o Trabalho Social tem como missão buscar a integração social e moral do indivíduo à sociedade [...]". Aparece aqui seu projeto profissional (em contraposição ao coletivo projeto ético-político) até agora implícito: a integração social e moral do individuo à sociedade. Cabe mencionar que "integração" não condiz com "lutas de classes" e que "inclusão" não elimina a "exploração". Estes são conceitos visivelmente reprodutores do sistema social e de seu status quo. Com tal "despolitização" da prática profissional, Di Carlo (p.13, grifo nosso) tenta então definir a profissão: "Entendemos por trabalho social real em parte o que 
se exerce bem na realidade atual... e junto com este, o que é possível exercer, diferenciando-os das construções puramente irrealizáveis". É isto o que o autor chama de “trabalho social real ou possível”, ou seja, "o possível” é “o real", reproduzindo assim o pensamento conservador que congela a "situação atual" (o possível e o impossível hoje), perpetuando-a para o futuro. Existe uma clara resignação ao possível. Nada mais funcional aos interesses das classes poderosas.

Afirmamos, primeiramente, que a tarefa do intelectual consiste na análise crítica da realidade (inclusive do "serviço social real"), sem mistificações, desvendando-a e desnudando-a. Por sua vez, ao perpetuar a (atual e suposta) "impossibilidade" de construir um Serviço Social crítico e comprometido com os valores já tratados, Di Carlo incorre em dois problemas: a) desconhece que seus interlocutores são enfáticos em afirmar que o sentido, o significado e o papel social da prática profissional não dependem apenas (nem fundamentalmente) da intencionalidade de seus atores (o que significaria um claro endogenismo e messianismo), mas das relações sociais, da correlação de forças e das estruturas e dinâmicas sociais - não é possível ignorar os determinantes históricos e estruturais; b) resigna-se à "inalterabilidade" (em um claro fatalismo), ignorando ou desconsiderando o relativo protagonismo dos profissionais para reconduzir, dentro de certos limites, sua prática a partir não somente de posições e de capacidades individuais, mas fundamentalmente de um coletivo projeto ético-político, construído a partir do debate, das alianças e das maiorias; além do que, a correlação de forças, a dinâmica e inclusive a estrutura sociais, também são históricos, e portanto não imutáveis.

(V) $\mathrm{O}$ apelo às microexperiências locais e o rechaço à função profisssional macrossocial.

Efetivamente, e derivado daquela tendência conservadora, talvez neste caso unido a uma reatualizada "crítica romântica ao capitalismo" 22 , os textos contestadores em geral incorporam um forte apelo às microexperiências singulares e localizadas (como campo de intervenção do assistente social); assim, o espaço de inserção direta do profissional pareceria conformar o horizonte da análise social. Não existe (ou não se consideram) estrutura social, relações entre classes, questões universais. Existem, sim, espaços comunitários locais, relações interpessoais, questões singulares.

Assim, partindo da idéia de que a realidade que interessa ao assistente social é apenas aquela que cerca sua prática profissional direta, privilegiam-se as concepções de "poder local", do "empoderamento", das "identidades particulares", rejeitando as teorias universais, as críticas da sociedade capitalista (especialmente a teoria marxista), da sociedade de classes, das relações entre classes (exploração, dominação, lutas de classes). Encontra-se aqui um desdobramento daquele conservadorismo: o curto-prazo, o local e singular e o imediato, hipotecando e deixando em segundo plano qualquer estratégia que tenha um horizonte de longo-alcance, universal $e$ mediato. O conservadorismo aqui assume a nova roupagem pós-moderna.

O Serviço Social não pode, com sua ação, "transformar" os determinantes macroestruturais, não pode eliminar a exploração, as contradições entre capital e trabalho; por isso (as correntes tradicionais e conservadoras da profissão) desconsideram a crítica ao papel que a profissão tem na estrutura social. Se o Serviço Social não determina a estrutura, então a estrutura não determina o Serviço Social, parecem afirmar estes autores. Algo assim como: "se a profissão não pode alterar a realidade macro, não é preciso se preocupar com ela". Então o Serviço Social não teria apenas um papel na estrutura social, mas papéis localizados, reduzidos a suas funções e atividades cotidianas. Para estes autores, são as atividades cotidianas dos profissionais que determinariam sua função social (e não o lugar que ocupam na dinâmica e estrutura sociais).

Não obstante, sem pretender que a intervenção do assistente social pudesse alterar as relações macroestruturais, é no espaço entre as classes, entre os interesses de classes, que se insere o profissional (não como mediador entre elas, claro), tendo, portanto, um papel (ético-político) em tais relações. $\mathrm{O}$ fato de que a intervenção profissional se desenvolva em torno de manifestações da "questão social" (desemprego, desnutrição, violência doméstica, fome, falta de acesso a determinados bens ou serviços, etc.) sem poder alterar seus fundamentos (exploração, lutas de classes, etc.) não desmente que o Serviço Social tenha um papel na estrutura social (eminentemente funcional na reprodução do sistema e do status quo e, contraditoriamente, o eventual reforço/fragilização de direitos e conquistas sociais).

(VI) A redução das respostas profissionais às situações emergenciais e imediatas e o conseqüente rechaço por estratégias e projetos de longo alcance.

Em consonância com o anterior, a proposta dos "contestadores" não apenas rechaça o universal, ao concentrar-se exclusivamente no local-singular, mas também rechaça o médio e o longo prazo ao esgotar suas energias no imediato.

Efetivamente, a dinâmica das demandas emergenciais e imediatas parece colocar o assistente social em um carrossel de respostas imediatas. A reprodução desta relação demanda-emergencial / resposta-imediata, leva o profissional (e a profissão) a uma lógica pragmática, movido pela "pre-ocupação".

Segundo Kosik (1989, p. 63, 64), no contexto do capital o homem, em sua alienada vida cotidiana, é tomado pela "preocupação". Para ele, a "preocupação" é o as- 
pecto fenomênico, alienado, da práxis do indivíduo. Estarse-ia assim substituindo a categoria de trabalho pela de ocupação e, portanto, a atividade criadora pela mera reprodução. Na vida cotidiana (desde que alienada, como o é no contexto capitalista), mais do que trabalhar, "ocupa-se" das coisas que requerem resposta direta e imediata e que são mantenedoras da ordem vigente. De acordo com este autor, "a passagem do 'trabalho' para a 'preocupação' reflete, de maneira mistificada, o processo de fetichização das relações humanas, [...] onde o mundo humano se manifesta à consciência diária $[. .$.$] como um$ mundo já feito".

Ou seja, a ocupação responde a necessidades singulares e imediatas dentro de um mundo dado e aparentemente imutável, naturalizado, perpetuado ${ }^{23}$. Tem uma prática apenas reprodutora, sem criar nada novo, portanto sem transformar. Assim, "na perspectiva da 'preocupação', o mundo objetivo e sensivelmente prático se dissolveu, transformouse no mundo dos significados traçados pela subjetividade humana. É um mundo estático no qual a manipulação, o ocupar-se e o utilitarismo, representam o movimento do indivíduo preso da solicitude, em uma realidade já feita e acabada cuja gênese está oculta" (KOSIK, 1989, p. 66).

Com isso, o assistente social tradicional apenas opera, manipula os instrumentos, os aparelhos, mesmo que não conheça a estrutura e sua dinâmica, nem a realidade além da fenomenalidade, da pseudoconcretude. Tem um conhecimento instrumental, operativo, não crítico, nem fundamental. Na verdade, ele é quem é instrumentalizado, manipulado, refuncionalizado para a reprodução do sistema que não conhece e que considera como dado, estruturalmente inalterável.

$\mathrm{O}$ assistente social tradicional (e o implícito projeto conservador) tende a se comportar desta maneira, "ocupando-se" com atividades dentro de um sistema considerado como já dado e imutável. Tende a se "preocupar" e a atuar de forma imediata, sem crítica, sem contribuir com a transformação, somente algumas modificações imediatas, localizadas, que respondam a suas carências diretas; atua de modo desarticulado, imediato, direto, nos "problemas" singulares, em uma ilusória realidade des-totalizada, deseconomizada, despolitizada, imutável, sem história. Este agente deixa de ser sujeito, passa a materializar-se em um sistema supra-histórico. Já não se faz (nem se pensa) a História, mas apenas histórias, singulares e cotidianas.

Neste sentido, dotar a prática profissional (que se desenvolve no cotidiano) de consciência humano-genéri$c a$, desalienada, é tarefa fundamental para romper com a instrumentalização que o capital faz desta prática. Para Lukács (apud ANTUNES, 1999, p. 169), "a vida cotidiana constitui a mediação objetivo-ontológica entre a simples reprodução espontânea da existência física e as formas mais elevadas de genericidade". Assim, a passagem das necessidades imediatas para o humano-genérico certa- mente não pode prescindir das formas de mediação presentes na práxis social e política.

Da mesma forma, é fundamental saturar a prática profissional de mediações, rompendo a relação imediata, utilitarista ou ativista, entre fato/percepção/resposta, permitindo o entendimento da vida cotidiana como instância particular que articula as situações singulares com a totalidade social. Desta forma, de acordo com Kosik (1989, p. 78), "para que o homem possa descobrir a verdade da cotidianidade alienada, deve conseguir desligar-se dela, liberá-la da familiaridade, exercer sobre ela uma 'violência"”.

A mediação (que não deve ser entendida como "intermediação" de situações de conflito) constitui, portanto, uma necessidade imperiosa para superar o imediatismo alienante. Segundo Pontes (2003), para Lukács a mediação se refere ao conjunto de particularidades que relaciona dialeticamente o universal e o singular. O cotidiano constitui, assim, um campo de mediações que, não obstante, não aparecem ao sujeito de forma direta, mas the são ocultas. É necessário, portanto, "superar o plano do imediatismo (da aparência) em busca da essência", o que exige "construir intelectualmente mediações para reconstruir o próprio movimento do objeto" (PONTES, 2003, p. 41). Para Pontes (2003, p. 210), "a captura pela razão dos sistemas de mediações (ocultos sob os fatos sociais) permite por meio de aproximações sucessivas ir-se negando à facticidade/imediaticidade, e desvelar-se as forças e processos que determinam a gênese (nascimento) e o modo de ser (funcionamento) dos complexos e fenômenos que existem em uma determinada sociedade" ${ }^{24}$.

Assim, o caminho que vai do abstrato para o concreto, partindo do concreto real, surge como a verdadeira possibilidade de superar a visão caótica da totalidade, os fatos isolados, supostamente auto-explicados tal como são apresentados de forma imediata, direta, ao sujeito, para uma compreensão mediada que apreenda a dialética da relação entre o universal e o singular, entre as leis tendenciais e as situações que enfrenta diariamente.

(VII) O retorno aos autores "clássicos" do Serviço Social e a tendência ao rechaço da reconceptualização.

Existe, entre os textos contestadores, a proposta de um retorno à bibliografia clássica do Serviço Social (Mary Richmond, Gordon Hamilton etc.). Algo assim como: "o estudo de sociólogos ou economistas sobre a estrutura social pode apoiar-se em teorias universais, mas o estudo da prática profissional do assistente social deve ser local e sustentado pelos textos clássicos 'específicos' da profissão". Sem nenhum afã de retirar a importância desta bibliografia para a formação profissional, tornam-se necessárias duas observações. A primeira é que aqueles textos não dão mais conta da realidade social atual a partir, fundamentalmente, das experiências que incorporam direitos sociais conquista- 
dos na passagem do século XIX para o XX, particularmente na realidade dos países latino-americanos, onde tais conquistas, mesmo que precárias, ocorrem tardiamente. São textos que remetem à história da profissão, mas não continuam a fazer sua história. A segunda e fundamental observação é que tais autores e textos "clássicos" são expressão do endogenismo, do positivismo e do funcionalismo que marcaram teórica e politicamente a gênese do Serviço Socia $^{25}$. Assim, a opção por estes autores tradicionais ou clássicos como referências centrais representa, sem dúvida, a opção por certas correntes do pensamento liberal/ positivista/funcionalista e, portanto, significam opções políticas: as ações corretivas localizadas e imediatas (do "disfuncional", do "desintegrado") por parte do profissional, que redundam na manutenção da estrutura social e do status quo.

Relacionado a isto se constata também, nos textos que contestam as propostas de construção coletiva de um "projeto ético-político profissional", um forte rechaço ao Movimento de Reconceptualização. Um exemplo é a contundente frase de Di Carlo (2004, p. 15), quando afirma que a Escola de Serviço Social uruguaia, assim como muitos professores e estudantes, nos anos 70, foi "ameaçada como todas as latino-americanas pela reconceptualização paralisante [...]", o que levou-o, naquela época, a defender o "Trabalho Social real"; ou a afirmação de Cortinas (2003, p. 28): “[...] da mesma forma que o fez há umas décadas a chamada etapa de 'reconceptualização', a qual freou durante anos o desenvolvimento da profissão."

A reconceptualização foi "paralisante"? Este não foi um movimento que, no acerto e no erro, questionou e tentou repensar o papel do profissional? Então não foi "paralisante", mas inovador. O problema para estes autores é discordar da reconceptualização justamente pelo que significou em termos de mudança, e não por ser "paralisante".

Mas estar ou não de acordo com este movimento é um direito. O equívoco é atribuir aos autores das "perspectivas histórico-críticas" a mesma condição daqueles postulados. Algumas pontuações precisam ser feitas neste caso. Primeiro, que efetivamente deve-se constatar que estes autores e sujeitos profissionais que postulam a construção coletiva de um "projeto ético-político" são herdeiros do espírito crítico e inovador que prevalecia no chamado Movimento de Reconceptualização. Segundo, que este movimento era extremamente heterogêneo e dentro dele diversas correntes formularam e responderam certas questões de forma variada, muitas vezes acertando, muitas vezes incorrendo em equívocos. Terceiro, que os autores das "perspectivas histórico-críticas" na atualidade realizam uma superação dos verdadeiros limites daquele movimento. Superação em relação a um pensamento progressista que, no entanto, não conseguiu romper com a lógica positivista ${ }^{26}$ no que se refere às tendências epistemológicas e metodológicas ${ }^{27}$, em relação ao endogenismo característico deste movimento, que muitas vezes autonomizou o desenvolvimento profissional das lutas de classes, do advento do capitalismo monopolista e do projeto do grande capital, do papel dos chamados Estados de Bem-Estar e de suas políticas sociais ${ }^{28}$; em relação a um certo rechaço ao Serviço Social institucional e à condenação da assistência como "assistencialismo" (as "perspectivas histórico-críticas" consideram a assistência como um direito conquistado pelo cidadão ${ }^{29} \mathrm{e}$ inclusive em relação ao "fatalismo" (que levou a impugnar a prática institucional, proclamando como única alternativa profissional a "mágica" passagem às "comunidades") e ao "messianismo" (onde a auto-proclamação de "agentes de transformação" e a nova denominação de "Trabalho Social" e "trabalhadores sociais" - ao invés de "Serviço Social" e "assistentes sociais"-, seriam suficientes para redirecionar o sentido da prática profissional ${ }^{30}$. Finalmente, reafirmam-se as observações de Netto frente à "crítica conservadora à reconceptualização"31.

(VIII) Tendência ao pós ou antimarxismo.

A heterogeneidade que caracteriza as "perspectivas histórico-críticas", como já vimos, invalida qualquer pretensão de adjetivá-las como "marxistas". Mas as diversas tendências marxistas na profissão sem dúvida fazem parte deste coletivo. Não obstante, uma característica presente na generalidade daqueles que contestam estas perspectivas consiste em um forte e claro anti ou pós-marxismo ${ }^{32}$.

Efetivamente, um dos avanços do movimento de reconceptualização foi ter estabelecido interlocução com o "pensamento marxista". No entanto, seu limite está marcado pela incorporação de um marxismo sem Marx; fundamentalmente mediante manuais e divulgadores ligados à Terceira Internacional ou marxismo oficial (Harnecker, Stalin), pensadores estruturalistas (Althusser, o jovem Poulantzas) ou de experiências revolucionárias localizadas (Mao, Che).

Os limites destas correntes são superados no debate atual, quando intelectuais marxistas do Serviço Social recorrem à própria obra de Marx (Iamamoto, Netto, Mota), a pensadores "dialéticos" de tradição marxista (pela via hegeliana) como Gramsci (Simionatto, Maciel, Franci G. Cardoso) ou Lukács (Netto, Barroco, Guerra), a historiadores marxistas como Hobsbawm, a pensadores desta tradição preocupados na contemporaneidade capitalista, como Mandel, Mészaros, Petras, Borón. Com estas mudanças de percurso, a contribuição marxista pósreconceptualização, superando os limites anteriores, está em condições de dar novas respostas a velhas e novas questões: gênese, fundamentos e significado social do Serviço Social; o papel do Estado de "bem-estar", as políticas sociais estatais e sua relação com a profissão; neoliberalismo e reforma do Estado; a prática profissional a partir do novo contexto social e mudanças nas deman- 
das institucionais, etc.

As contestações às "perspectivas histórico-críticas", em boa parte, estão saturadas de anti e de pós-marxismo; porém não conseguem visualizar estas mudanças de percurso no atual debate dos autores marxistas, estabelecendo, assim, suas críticas em função dos limites existentes no contexto reconceptualizador. No entanto, é possível identificar alguns textos contestadores a estas "perspectivas histórico-críticas", que provêm de vertentes marxistas (como são os casos de Cortinas e San Giácomo); em tais casos observa-se como as contestações, visivelmente, partem dos mesmos limites anteriormente presentes no "marxismo invadido da lógica positivista".

(IX) A negação ao debate acadêmico e aberto, mediante diversos recursos.

É sabido, nas teorias da comunicação humana, que o "rechaço ao conteúdo" de uma mensagem não equivale ao "rechaço à comunicação", ao diálogo. Debater, discutir, confrontar idéias (inclusive rechaçá-las), tudo isso faz parte da comunicação, especialmente do debate acadêmico. Por outro lado, "rechaçar a comunicação", evitar o diálogo, escapar do debate de idéias, pode ser o resultado da "desqualificação" de seu interlocutor ${ }^{33}$. Seguem alguns exemplos de características geralmente presentes em tais textos, que configuram uma tendência à "desqualificação do interlocutor" e, portanto, ao "rechaço ao debate" acadêmico e aberto:

a) O desconhecimento de seus interlocutores e de sua obra: efetivamente, chama atenção o profundo desconhecimento da obra e da biografia dos interlocutores que pretendem contestar. Exemplos como o de Cortinas (2003) onde realiza suas considerações sem sequer ter acessado os textos que "contesta", apenas a partir da leitura do pequeno ensaio de Di Carlo (2001). Ou o caso de Porzecanski (2001), que identifica a obra de Iamamoto em um texto de 1992, uma década depois de seu texto original. Ou inclusive o caso de San Giácomo (DICARLO, 2004), que renomeia esta autora como "Lamamoto". Exemplos como estes são apenas amostras de uma leitura parcial e apressada dos interlocutores e das obras que pretendem enfrentar. Algo inadmissível no debate acadêmico responsável.

b) A tergiversação e a deformação do pensamento de seus interlocutores: já teceu-se algumas considerações sobre as tergiversações que Porzecanski realiza sobre os postulados de Iamamoto e de Montaño (MONTAÑO, 2002). Registra-se algo semelhante no caso de Cortinas (2003a) sobre o texto de Netto, que aqui excederia os espaços para este artigo. Quando desconhecimento do interlocutor e tergiversação de seus postulados andam juntos, o resultado é nefasto: a absoluta parcialidade e relativismo no debate. Mas tem mais. c) A falta de referencialidade e a ausência quase sistemática de citações: é desconcertante constatar como nestes textos, quase em sua totalidade, não se recorre a referências e citações de seus interlocutores. É possível observar-se, em alguns casos, ausência de bibliografia ou daquela referente aos autores que "contestam"; em outros casos, o debate sobre supostos "postulados" de seus interlocutores sem recorrer a citações identificando fontes. $\mathrm{O}$ resultado disso é claro: o leitor não tem como comprovar se a versão exposta realmente é fiel e reflete fidedignamente o pensamento de seu autor ou se, pelo contrário, está ali configurada uma tergiversação. Assim, desconhecimento do interlocutor, tergiversação de seu pensamento e ausência de citações e referências (necessárias ao debate acadêmico) permitem que autores debatam com as imagens que eles mesmos podem construir sobre os postulados de seus interlocutores.

d) Partir de axiomas e verdades irrefutáveis: já tratado neste artigo como "naturalização", o partir de "axiomas" - "missões" supostamente dadas e inalteráveis, "compromissos" naturais e óbvios, etc. descaracteriza o processo de construção coletiva a partir do debate de idéias, substituindo-o por estas supostas "verdades" já dadas.

e) Estigmatização de seus interlocutores: observase, finalmente, o rechaço ao debate mediante o recurso da "estigmatização" de seus interlocutores. Em diversas passagens dos vários textos contestadores das "perspectivas histórico-críticas", seus autores são adjetivados como "inquisidores medievais" (Porzecanski, sobre Iamamoto), "um materialista pretensamente dialético" (Cortinas, sobre Netto), "inimigos internos da profissão" (Di Carlo, sobre Montaño), para dar apenas alguns exemplos. É incompreensível como se pode defender um debate (na polêmica e no confronto de idéias) aberto, pluralista, acadêmico com este tipo de recursos.

$\mathrm{Na}$ verdade o que se evidencia é una forma de evitar o confronto de idéias, de fugir do debate.

\section{Comentários finais}

Em síntese, frente à proposta de construir coletivamente um projeto ético-político que dote o assistente social de um perfil crítico, de um sentido político e de um comportamento ético em sua prática profissional, ampliando sua incidência nos processos em que intervém, se interpõe uma "contestação" que pretende restaurar o sentido social tradicional (e, portanto, conservador) da profissão.

Substitui a análise crítica da história pela naturalização do papel social da profissão. Substitui, assim, a cons- 
trução coletiva de um projeto profissional pela vontade individual de cada assistente social, embora mais submetido (sem sabê-lo ou, inclusive, negando-o) aos determinantes estruturais e à correlação de forças existentes (hegemônicas do capital).

Um projeto que tenta dar maior protagonismo ao coletivo profissional em uma direção ética e política (a partir de determinados valores), ou a ação voluntária e individual, que acredita na auto-atribuição do sentido da prática profissional e ao fazê-lo, sem saber e sem querer, se submete (ou se resigna) a uma ação meramente reprodutora. Esta parece ser a disjuntiva em que está imersa esta profissão hoje.

\section{Recebido em 08.04.2006. Aprovado em 02.06.2006.}

\section{Referências}

ANTUNES, R. Os sentidos do trabalho. Ensaio sobre a afirmação e a negação do trabalho. São Paulo: Boitempo, 1999.

BORGIANNI, E.; MONTAÑO, C. La Política Social hoy. São Paulo: Cortez, 2000a. 304 p. (Biblioteca Latinoamericana de Servicio Social, n. 5).

Metodología y Servicio Social hoy en debate. São Paulo: Cortez, 2000b. 232 p. (Biblioteca Latinoamericana de Servicio Social, n. 6).

BORGIANNI, E.; MONTAÑO, C.; GUERRA, Y. Servicio Social Crítico. Hacia la construcción del nuevo proyecto ético-político profesional. São Paulo: Cortez, 2003. 352 p. (Biblioteca Latinoamericana de Servicio Social, n. 6).

COLMAN, E. O que é Serviço Social? Vigência de um 'velho' problema e desafio para a formação Professional. Serviço Social em Revista, Londrina, UEL, n. 1, 1998.

CORTINAS, R. A propósito de algunas tendencias críticas en el Servicio Social Profesional. Revista de Trabajo Social, Montevideo, Eppal, n. 27, 2003.

Debatiendo con José Paulo Netto. Análisis crítico del libro 'Capitalismo monopolista y Servicio Social'. Revista de Trabajo Social, Montevideo, Eppal, n. 28, 2003a.

DI CARLO, E. Reflexiones y refutaciones. In: DI CARLO, E.; SAN GIACOMO, O. Una introducción al Trabajo Social. Univ. Mar del Plata, 2001.

(Org.). La profesión de Trabajo Social: naturaleza, significado social y formas de acción profesional. Univ. Nacional Mar del Plata, 2004.

FOUCAULT, M. O nascimento da medicina social. In: Microfisica do poder. Rio de Janeiro: Graal, 1985.

IAMAMOTO, M. Renovação e conservadorismo no Serviço Social. Ensaios críticos. São Paulo: Cortez, 1992.

Servicio Social y división del trabajo. Un análisis crítico de sus fundamentos. São Paulo: Cortez, 1997. 224 p. (Biblioteca Latinoamericana de Servicio Social, n. 2).
A questão social no capitalismo. Revista Temporalis, Brasília, Abepss, n. 3, 2001.

KOSIK, K. Dialética do concreto. São Paulo: Paz e Terra, 1989.

MONTAÑO, C. La naturaleza del Servicio Social. Un ensayo sobre su génesis, su especificidad y su reproducción. São Paulo: Cortez, 1998. 208 p. (Biblioteca Latinoamericana de Serviço Social, n. 4)

. O Serviço Social frente ao neoliberalismo. Mudanças na sua base de sustentação funcional-ocupacional. Serviço Social \& Sociedade, São Paulo: Cortez, n. 53, 1997.

Ladran, Sancho! Señal que cabalgamos. Réplica a algunos ensayistas desconcertados. In: FORO SURÁ, Costa Rica, enero 2002, n. 66. Disponible en $<$ http://cariari.ucr.ac.cr/ trasoc/ suradoc.htm>.

MOTA, A. E. Cultura da crise e Seguridade Social. São Paulo: Cortez, 1995.

NETTO, J. P. A crítica conservadora à Reconceptualização. Serviço Social \& Sociedade, São Paulo: Cortez, n. 5, 1981.

Capitalismo monopolista y Servicio Social. São Paulo: Cortez, 1997. 200 p. (Biblioteca Latinoamericana de Servicio Social, n. 1).

PALMA, D. La práctica política de los profesionales. El caso del Trabajo Social. Lima, Celats, 1985.

PETRAS, J. Neoliberalismo: América Latina, Estados Unidos e Europa. Blumenau, FURB, 1999, 433 p. (Coleção Sociedade e Ambiente, n. 3).

PONTES, R. Mediación: categoría fundamental para el trabajo del asistente social. In: BORGIANNI, E.; GUERRA, Y.; MONTAÑO, C. (Orgs.). Servicio Social Crítico. São Paulo: Cortez, 2003. 352 p. (Biblioteca Latinoamericana de Servicio Social, n. 10).

PORZECANSKI, T. Algunas cuestiones disciplinares del Trabajo Social. Revista Fronteras, Montevideo, Universidad de la República-DTS, n. 4, 2001.

WATZKLAWICK et al. Teoría de la comunicación humana. Interacciones, patologías y paradojas. Barcelona: Herder, 1987.

\section{Notas}

1 Ver Borgianni; Montaño (2000a, b).

2 Ver Iamamoto (1997, cap. II) e Netto (1997, cap. I).

3 Ver Montaño (1998, cap. 1).

4 Ver Montaño (1997).

5 Sobre isto ver Iamamoto (1997, p. 143 e ss.), ao tratar do "profissional da coerção e do consenso"; e Guerra (BORGIANNI, GUERRA e MONTAÑO, 2003,p. 185 e ss.), sobre a "instrumentalização do Serviço Social".

6 Ver Montaño (2002).

7 Ver Laurell (BORGIANNI e MONTAÑO, 2000a, b) e Montaño (2002). 
8 No primeiro caso, privatização/desnacionalização/ desestatização, eliminação de direitos sociais, civis, políticos e trabalhistas, (contra) reformas estatais e reestruturações produtivas para desonerar o capital em suas responsabilidades fiscais e tributárias, criando novas áreas lucrativas. No segundo caso, nacionalização/publicização/ estatização, estimulando e protegendo a indústria mediante a injeção de recursos públicos para o capital, mas reconhecendo e respondendo demandas e necessidades de setores trabalhistas. Finalmente, no projeto revolucionário, o desenvolvimento de uma sociedade sem classes fundada na emancipação humana e organizada mediante a associação de livres produtores, a erradicação do comando do capital, da exploração e das formas de dominação.

9 “Questão social", entendida por Iamamoto (2001,p. 11) como "indissociável do processo de acumulação (capitalista) e dos efeitos que produz sobre o conjunto das classes trabalhadoras (desemprego, fome, pobreza, emigração, etc.), que se encontra na base da exigência de políticas sociais públicas". Assim, expressa tanto "disparidades econômicas, políticas e culturais das classes sociais, mediatizadas por relações de gênero, características étnico-raciais e formações regionais, pondo em movimento as relações entre amplos segmentos da sociedade civil e o poder estatal", como também "envolve simultaneamente uma luta franca e aberta pela cidadania". Ou seja, "A questão social tem a ver com a emergência da classe operária (a partir do contexto da revolução industrial) e seu ingresso no cenário político (constituindo-se como classe-para-si)" (idem, p. 17).

10 Citemos apenas alguns: Di Carlo (2001, 2004.), Cortinas (2003, 2003a), Porzecansk (2001), Colmam (1998), entre outros

11 Na segunda Tese sobre Feuerbach, Max afirma que "é na prática (social, histórica) onde o homem tem que demonstrar a verdade".

12 Prova disso são os seminários que começaram a surgir neste início de século sobre o Serviço Social Crítico e sobre o Projeto Ético-Político Profissional. Ver, a modo de exemplo: a) Seminario Internacional: Identidad, Tendencias y Proyecto Ético-Político del Trabajo Social. Universidad Mayor de San Andrés. La Paz, Bolivia, 19 a 22 de agosto de 2003; b) Jornada de reflexión: La dimensión política del ejercicio profesional. Universidad Nacional de Córdoba, 1 e 2 de julho de 2005; c) Encuentro Latinoamericano de Trabajo Social. La formación y la intervención profesional en la sociedad contemporánea: hacia la construcción de un proyecto ético-politico. La Plata, Argentina, 26 e 27 de agosto, 2005; d) I Encuentro Latinoamericano de Trabajo Social. El Trabajo Social Crítico en el contexto latinoamericano, propuestas alternativas para la construcción de una nueva sociedad. Bogotá, Colombia, 5 a 8 de outubro de 2005; e) El trabajo comunitario, intervención social, política y ética. Mendoza, Argentina, 2 a 4 de dezembro de 2005; f) Seminario Nacional: Construyendo la ciudadanía: desafios e escenarios do Trabajo Social Latinoamericano. Universidad Católica de Santiago de Guayaquil, 11 e 12 de julho de 2005. Além de textos, conferências e palestras, cursos realizados sobre estes temas.
13 Todas as citações foram traduzidas pelo autor

14 UFRJ: ver Porzecanski (2001, p. 75,77); PUC-SP: ver Di Carlo (2004, p. 10). Sintomático é que cada um destes autores atribua institucionalidade ao debate, "coincidentemente" com os acordos de mestrado nos respectivos países: Argentina-Brasil (mediante o convênio UNLP e PUC-SP) e Uruguay-Brasil (UDELAR e UFRJ).

15 Ver Di Carlo (2001, p. 26-27; 2004, p. 10).

16 Lembrando que Prozecanski, San Giácomo, Di Carlo e Cortinas são todos uruguaios.

17 Ver Di Carlo (2004, p. 10).

18 Sobre o "endogenismo" profissional ver Montaño (1998, cap. 1).

19 Como é exemplo a afirmação de Di Carlo (2004, p. 14), ao determinar que pareceria que os "críticos do Serviço Social real ou possível querem destruir esta profissão", correndo o "risco objetivo da aniquilação da profissão".

20 Como corretamente observa Iamamoto (1997), "fatalismo e messianismo são ambos prisioneiros de uma análise da prática social que não dá conta da historicidade do ser social gerado na sociedade capitalista".

21 Sobre isto ver Iamamoto (1997, p. 104, 108 e ss.)

22 Sobre a "Crítica romântica do capitalismo" ver: Marx (A miséria da filosofia); Marx e Engels (A ideologia alemã); Engels (Do socialismo utópico ao socialismo científico); Lukács (O assalto à razão); Netto (Lukács e a crítica da filosofia burguesa).

23 Para Kosik (1989, p. 64), “o ocupar-se é o comportamento prático do homem no mundo já feito e dado; é manejo e manipulação dos aparelhos no mundo, mas não é criação do mundo humano".

24 Pontes (2003, p. 216-7) exemplifica da seguinte forma: "Quando um problema de um pequeno agrupamento de pessoas (ou até de um único indivíduo) [...] passa a ser compreendido como pertencente a tantos outros [...], então, aquela situação única, que se afigurava no plano da singularidade como problema individual-familiar, mediatizase. Essa mediação se dá pelas leis sociais e particulariza pelas determinações históricas, ganhando, por aproximações sucessivas, concretude no entrecruzamento dos complexos sociais que compõem a realidade".

25 Sobre isto ver Iamamoto (1997, p. 159 y ss.), ao discutir "a herança conservadora do Serviço Social".

26 Sobre isto ver Quiroga (BORGIANNI; MONTAÑO, 2000b, p. 9 e ss).

27 Ver Lima e Rodríguez; Netto; Montaño (ibid, p. 35-51, 121 e ss.)

28 Sobre isto ver Iamamoto e Netto (IAMAMOTO, 1992, p. 131) e Montaño (1998, p. 5 e ss).

29 Ver Yazbek (BORGIANNI; MONTAÑO, $2000 \mathrm{a}, \mathrm{b}$ ).

30 Sobre isto ver Iamamoto (1997, p.183). 
31 Mencionemos apenas três das críticas conservadoras que Netto (1981, p. 66, 68-69) comenta: a) "a reconceptualização determinou a ideologização profissional"; para Netto, "o Serviço Social clássico e tradicional - assim como qualquer modalidade de intervenção sociopolítica - sempre esteve matrizado por parâmetros ideológicos inequívocos". Assim, a "reconceptualização mostrou que o Serviço Social enquanto profissão nunca ultrapassou o horizonte ideológico burguês", o que mostra que "o verdadeiro problema não consiste em integrar ou não componentes ideológicos consiste em qual componente ideológico deve ser integrado"; portanto, "no fundo, o que se contesta no processo de reconcpetualização não é 'ter ideologia', mas 'ter ideologia de esquerda"; b) "a reconceptualização desprofissionalizou o Serviço Social pela via da politização"; Netto comenta que é inevitável que uma profissão se veja perpassada pelas dinâmicas, tendências e relações sociais num determinado contexto; nesse sentido, "considerar o processo de reconceptualização 'politizador' porque refletiu e assimilou as marcas fulcrais de seu tempo (e onde profissionais chegaram a fazer opções políticas), significa ... reconhecer a incapacidade do Serviço Social tradicional para se adequar às novas demandas sociais"; c) "a reconceptualização instaurou um hiato entre os centros de formação e as agências de intervenção"; afirma o autor que "não cabe (aos centros de formação) simplesmente suprir a demanda real e imediata posta pelo mercado de trabalho. A formação universitária...prepara quadros profissionais considerando tanto a realidade dada como detectando as tendências virtuais que condicionarão novas demandas. A formação não pode ser posta a serviço das necessidades imediatas, que neste caso sempre foram reduzidas às necessidades institucionais das agências de intervenção" (agências estas representantes, direta ou indiretamente, dos hegemônicos interesses do grande capital).

32 Petras (1999, p. 17-20), caracterizando o "pós-marxismo" como a postura intelectual da moda, a partir do espaço deixado pela esquerda reformista com o triunfo do neoliberalismo, determina dez argumentos básicos que compõem tal corrente de pensamento: 1) o suposto fracasso do socialismo e o fim das ideologias; 2) a acusação de reducionismo marxista na ênfase da determinação de classe; 3) o Estado como inimigo da democracia e da liberdade, propondo como contratendência o protagonismo da sociedade civil; 4) a afirmação de que a planificação centralizada leva à burocracia, enquanto o mercado conduz a um maior consumo e distribuição eficiente; 5 ) a preferência do poder estatal pelas lutas localizadas mais do que pelas de esquerda tradicionais; 6) a idéia de que as revoluções sempre acabam mal, preferindo lutar pela consolidação da democracia [dentro do sistema]; 7) o enterro da classe como categoria, erguendo em seu lugar outras identidades; 8) o descrédito sobre as lutas de classes, preferindo a cooperação governamental e internacional [para responder às necessidades na busca do bem comum]; 9) a desconsideração de imperialismo como fenômeno significativo; 10) a necessidade de que as organizações populares não apenas respondam às demandas sociais, mas que se voltem cada vez mais para a captação de recursos externos.
33 Afirmam Watzklawick e colaboradores (1987, p. 76) que com o recurso da "desqualificação" um sujeito "pode se comunicar de maneira tal que sua própria comunicação ou a do outro fiquem invalidadas. As desqualificações abarcam uma ampla gama de fenômenos comunicacionais, tais como auto-contradições, incongruências, mudanças de tema, tangencializações, orações incompletas, mal-entendidos, estilo obscuro ou maneirismos idiomáticos, interpretações literais da metáfora e interpretação metafórica das expressões literais, etc".

\section{Carlos Montaño}

montano@ess.ufrj.br

Universidade Federal do Rio de Janeiro

Escola de Serviço Social

Av. Pasteur, 250 - Campus Praia Vermelha

Rio de Janeiro - RJ

CEP: 22290-140 